\title{
Learn Asset Management based on PTPN 9 Case - Preliminary Overview of the Institution, the Function, and the General Business Assets
}

\author{
Soedarmawan Soewardi ${ }^{1, a)}$, Hitapriya Suprayitno ${ }^{2, b)}$ \& Ria Asih Aryani Soemitro ${ }^{2, c)}$ \\ ${ }^{1)}$ Former Production Director, PTPN-9, Semarang \& Surakarta, Indonesia. \\ ${ }^{2)}$ Civil Engineering Dept., Institut Teknologi Sepuluh Nopember (ITS), Surabaya, Indonesia. \\ Correspondent : ${ }^{a)}$ darmoadinegoross@gmail.com, ${ }^{b}$ suprayitno.hita@gmail.com \& \\ ${ }^{c}$ ria@ce.its.ac.id.
}

\begin{abstract}
Asset Management in general and IFAM specifically is very important. The knowledge and science need to be developed step by step. PTPN-9 can be used as an excellent Case Study. A general overview was developed as a base for studying the AM in PTPN-9. PTPN-9 is a state-owned-enterprise, whose duty is to manage the business of yearly plantations and seasonal plantations (sugar-cane plantations and sugar factories), in Central Java. Practically, all of the yearly plantations and seasonal plantations (sugar factories) were started by the Dutch, since the colonialization era. As the first step, this paper observes the production assets, the product, and the market. As production assets, the enterprise has 15 yearly plantations and 8 seasonal plantations. As products, it has 7 consumption commodities, 10 commercial commodities, 8 agro-tourism objects, and 14 restaurants and coffees. The enterprise sells its products into the international market and the domestic market.
\end{abstract}

Keyword : asset management, infrastructure \& facility asset management, general overview, PTPN-9.

\section{INTRODUCTION}

Asset Management (AM) in general and Infrastructure \& Facility Asset Management (IFAM) are important to be learned, known, practiced, mastered, and developed. This journal, the JIFAM - Journal of Infrastructure \& Facility Asset Management, is established to develop the Knowledges and Science of IFAM, and of course with AM in general.

One of the easiest ways to learn the AM and the IFAM is by observing and learning from real cases. It is good to observe institutions that have asset management work to execute their business. To have a good comprehension of the problem, the observation must be started from the general observation on its institutional aspect, its functional aspects, and followed by its assets understanding. Such a learning method has been done already by observing a university medical center (Ratnasari \& Suprayitno, 2019). This method needs to be repeated to observe other institutions. The observation and learning must be executed, systematically, by observing step-by-step from the whole general overviewed, followed by special cases more in detail oneby-one.

PT Perkebunan Nusantara 9 (PTPN-9) is a state-owned-enterprise (SOE) for AgroBusiness Sector. It has an enormous production asset, product variety, and market variety. PTPN-9 can function as an excellent Case Study to be observed, to learn AM and IFAM. Meanwhile, state-owned-enterprise is vital for Indonesia, and in general, its performance needs to be evaluated. This paper can function as the first step toward enterprise performance evaluation (Fitriningrum, 2006; PTPN-9, 2017; Soejono, 2006; Soejono \& Heriyanto, 2010). 
The observation should be executed step-by-step started from a general preliminary overview of the enterprise.

This paper presents the basic preliminary overview of PTPN-9, on its institutional aspects, functional aspects, and general business assets. This knowledge will be used further on to learn the AM and IFAM in PTPN-9.

\section{RESEARCH METHOD}

This research is designated to produce an overview description of PTPN-9, oriented toward a step-by-step Asset Management Study on it. The information was gathered from the PTPN-9 documents, academic works on PTPN-9, related mass media information, the PTPN9 Website, and interviews.

\section{INSTITUTION, FUNCTION, ASSETS, PRODUCTS, AND MARKETS}

\section{Research Objective}

The research objective is to have an Overview Description of PTPN-9 to be used for developing Asset Management Study and Research, with PTPN-9 taken as a case. The asset management study and research will be developed step-by-step. The overview information of the PTPN 9 is organized into the historical aspects, the institutional aspect, the functional aspect, the production asset, the product, and the market.

\section{Previous Works}

Several related kinds of research have been done and published in Jurnal Manajemen Aset Infrastruktur \& Fasilitas (JMAIF) and Journal of Infrastructure \& Facility Asset Management (JIFAM). The first work published is a scientific paper defining the AM, and the IFAM (Soemitro \& Suprayitno, 2018; Suprayitno \& Soemitro 2018). This work has been followed by a special reflection on IFAM for Public Infrastructure. This reflection indicates that managing Public Infrastructure is regulated by Law on State Treasury and Government Regulation on Management of State and Region Asset as the base (ISO 55000; PP27/14; Suprayitno \& Soemitro, 2019; UU 1/04). After these two papers discussing the basic knowledge, a Basic Learning for IFAM has been done and published, by using ITS Medical Center as the case. This kind of paper needs to be developed and continued by other papers, more in-depth (Ratnasari $\&$ Suprayitno, 2019). Some other works concerning more detailed topics, such as infrastructure demand, infrastructure operation, infrastructure \& facility evaluation, factor analysis, infrastructure financing, and others, have been done also (Al Bari, 2019; Chilongola et al, 2020; Firlandy et al, 2020; Eryani et al, 2020; Kye \& Susilawati, 2020; Muhtadi et al, 2019; Slamet \& Fajarwati, 2020; Soejono \& Heriyanto, 2010; Soemitro \& Suprayitno, 2020; Suprayitno, 2015; Suprayitno et al, 2020; Teguh, 2020).

\section{PTPN 9 - History}

All plantations and sugar factories managed by PTPN-9 (Perseroan Terbatas Perkebunan Nusantara 9) were developed during the Dutch colonialization era. These yearly plantations and seasonal plantations (sugar-cane plantations and sugar factories) were nationalized in 1957 and managed by BPU PPN (Badan Pelayanan Umum - Perusahaan Perkebun Negara). In 1968, the management was handover to PN Perkebunan 16 \& PN Perkebunan 15. Afterward, on 11 March 1996, under Government Regulation 14/96, the state-owned-enterprises in the plantation related sector were restructured. All plantation state-owned-enterprises in Central Java Province, the PTP XV, the PTP XVI, the PTP XVIII, and PTP XVII Gunny Sack were merged into PTPN-9 (PTPN-9, 2017). 


\section{PTPN 9 - Institutional Aspects}

The PTPN 9 is a State-Owned-Enterprise (SOE). Its main task is to operate all of the National Public Plantations and National Sugar Factories in Central Java, together with developing and commercializing its product. The head office is located in Semarang and the second main office in Surakarta. The PTPN 9 operates under a National Plantation Holding Company called PTPN-3 (PTPN-9, 2017).

\section{PTPN 9 - Functional Aspects}

The PTPN-9 main task is to manage the business of 15 national yearly plantations and 8 national seasonal plantations (sugar-cane plantations and sugar factories), as well as to develop the business. All of the plantations are scattered all over Central Java. The plantations consist of rubber plantations, coffee plantations, tea plantations, cacao plantations, and nutmeg plantations. The 8 sugar-cane seasonal plantations (sugar factories) are all scattered all over Central Java. All of the 23 plantations were built by the Dutch (PTPN-9, 2017).

From the point of view of Asset Management, the PTPN-9 main function can be presented through a diagram shown in Figure 1. Regarding the main function related to assets, we have to consider that PTPN-9 has production assets, products, and markets to be managed.

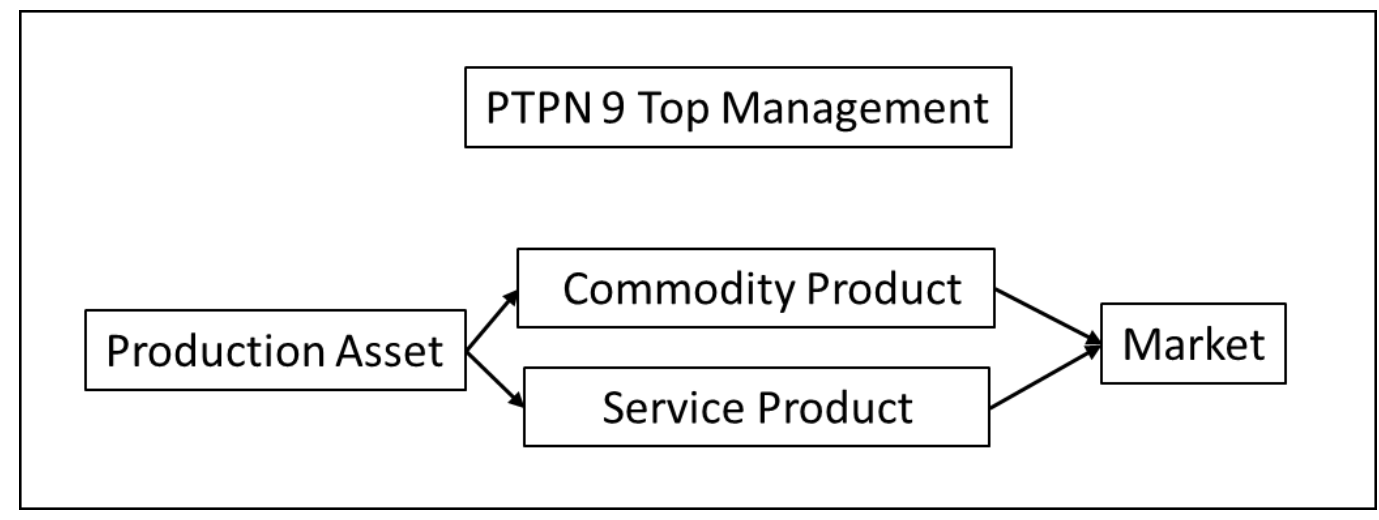

Figure 1. Main Function of PTPN 9

\section{PTPN 9 - Production Asset}

The first asset to be observed is of course the production asset. The production asset is the physical asset producing product to be commercialized. The PTPN-9 has two groups of production assets: the yearly plantations and the seasonal plantations (sugar-cane plantations and sugar factories). PTPN-9 has been organized into three Division, Division 1 manages the yearly plantations, Division 2 manages the seasonal plantations (sugar-cane plantations and sugar factories), and a new Division 3 manages the agro-tourism, hotel, restaurant, and coffees business (PTPN-9, 2017).

\section{Yearly Plantations}

PTPN-9 manages 15 yearly plantations consists of 4 kinds of plant, i.e. rubber, tea, coffee, and cacao. Apart of these there is a small nutmeg plantation. The 15 yearly plantations scattered all over Central Java, from the easternmost in Pati Regency to the westernmost in Brebes Regency, from the northernmost in Jepara Regency to the southernmost in Pacitan Regency. The coffee plantations are all robusta lowland plantations. While PTPN-9 has both lowland and highland tea plantations. While the rubber plantation, cocoa, and nutmeg plantation are all lowland plantation. The list of plantations is presented in Table 1 as follows (PTPN-9, 2017). 
Table 1. List of Division 1 - Yearly Plantations

\begin{tabular}{|r|l|l|l|l|}
\hline \multirow{2}{*}{ No } & \multirow{2}{*}{ Name } & \multirow{2}{*}{ Plant } & Kecamatan & Regency \\
\hline 1 & Warnasari & rubber & Dayeuhluhur & Cilacap \\
\hline 2 & Kawung & rubber & Cimanggu & Cilacap \\
\hline 3 & Krumput & rubber & Banyumas & Banyumas \\
\hline 4 & Kaligua & tea & Paguyangan & Brebes \\
\hline 5 & Semugih & tea, cacao & Moga & Pemalang \\
\hline 6 & Blimbing & rubber & Karanganyar & Pekalongan \\
\hline 7 & Jolotigo & rubber, tea, cacao & Talun & Pekalongan \\
\hline 8 & Siluwok & rubber & Grinsing & Batang \\
\hline 9 & Sukamangli & rubber, coffee & Sukorejo & Kendal \\
\hline 10 & Merbuh & rubber & Boja & Kendal \\
\hline 11 & Ngobo & rubber, coffee, cacao, nutmeg & Bergas & Semarang \\
\hline 12 & Getas & rubber, cacao & Pebelan & Semarang \\
\hline 13 & Batujamus & rubber, coffee & Kerjo & Karanganyar \\
\hline 14 & Jollong & coffee & Gembong & Pati \\
\hline 15 & Balong & rubber, cacao & Keling & Jepara \\
\hline & & & & \\
\hline
\end{tabular}

The map of plantation locations is presented in Figure 2 as follows. It can be seen that the plantations are scattered all over the Central Java Province.

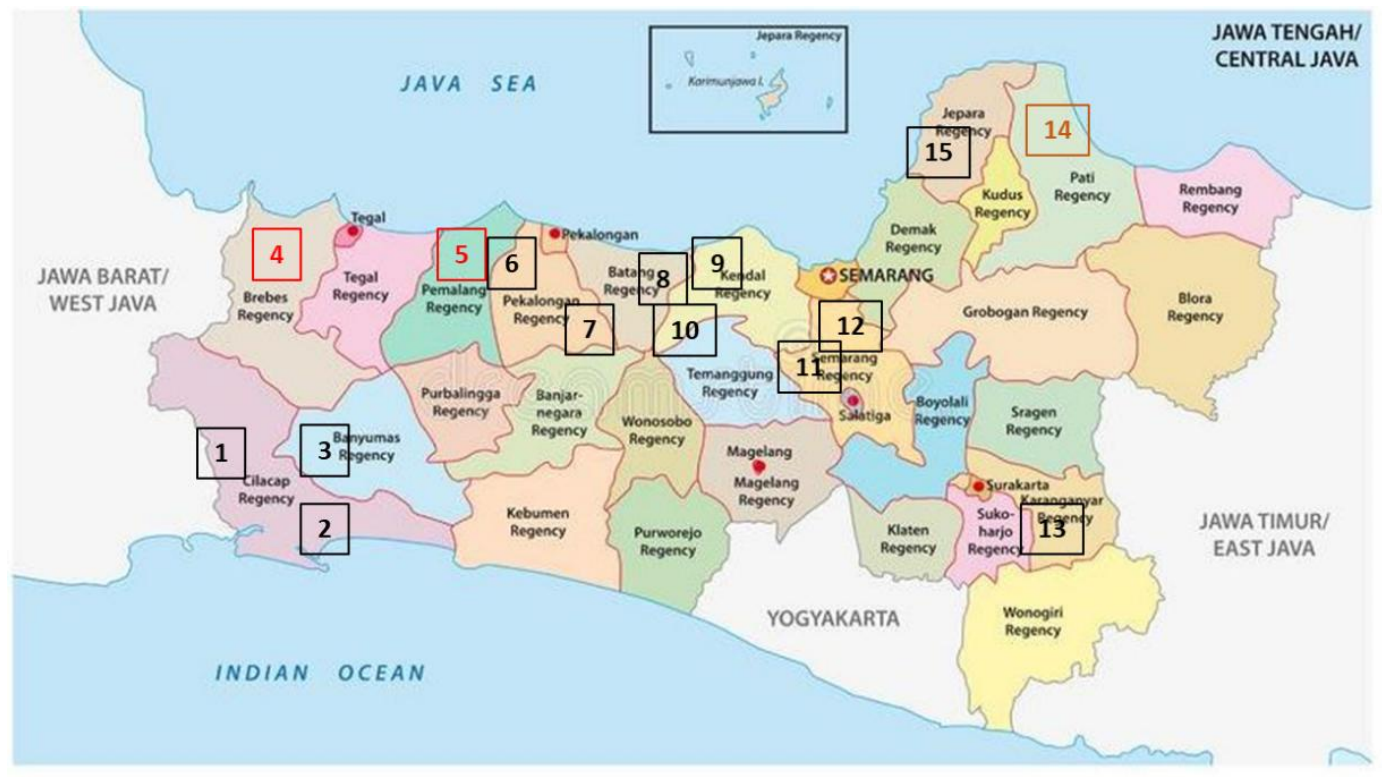

Figure 2. Location of Seasonal Plantations as Production Asset.

As an illustration, several examples of plantation photos are presented in Figure 3. The four photos are, from the left to the right, tea plantation, coffee plantation, cacao plantation, and rubber plantation. 


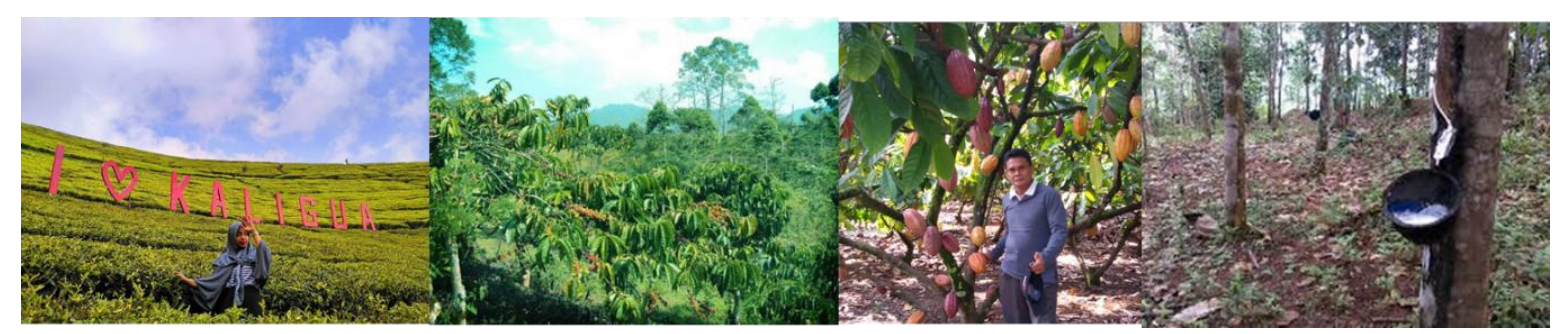

Figure 3. Example of Plantation Photos.

\section{Seasonal Plantation (Sugar-Cane Plantations and Sugar Factory)}

As seasonal plantations, PTPN-9 owns 8 sugar cane plantations together with 8 sugar factories. Again, these are scattered all over Central Java Province. The easternmost is located in Sragen Regency, while the westernmost is located in Brebes Regency. The northernmost is located in Kudus Regency, while the southernmost is located in Klaten Regency. The list of the 8 sugar factories is presented in Table 2 as follows. All of the sugar-cane plantations are located in the surrounding of sugar factories (PTPN-9, 2017).

Table 2. List of Division 2 - Sugar Factory \& Sugar-Cane Plantation

\begin{tabular}{|r|l|l|l|}
\hline \multirow{2}{*}{ No } & $\begin{array}{l}\text { Sugar Factory } \\
\text { \& Plantation }\end{array}$ & \multicolumn{2}{|c|}{ Location } \\
\cline { 3 - 4 } & Kecamatan & Regency \\
\hline 1 & Jatibarang & Jatibarang & Brebes \\
\hline 2 & Pangka & Pangka & Slawi \\
\hline 3 & Sumberharjo & Pemalang & Pemalang \\
\hline 4 & Sragi & Sragi & Pekalongan \\
\hline 5 & Rendeng & Kota Kudus & Kudus \\
\hline 6 & Mojo & Sregen Kulon & Sragen \\
\hline 7 & Gondang Baru & Jogonalan & Klaten \\
\hline 8 & Tasikmadu & Tasikmadu & Karanganyar \\
\hline
\end{tabular}

The location map of the sugar factories is presented in Figure 4 as follows. It can be seen that the sugar factories are scattered all over Central Java Province.

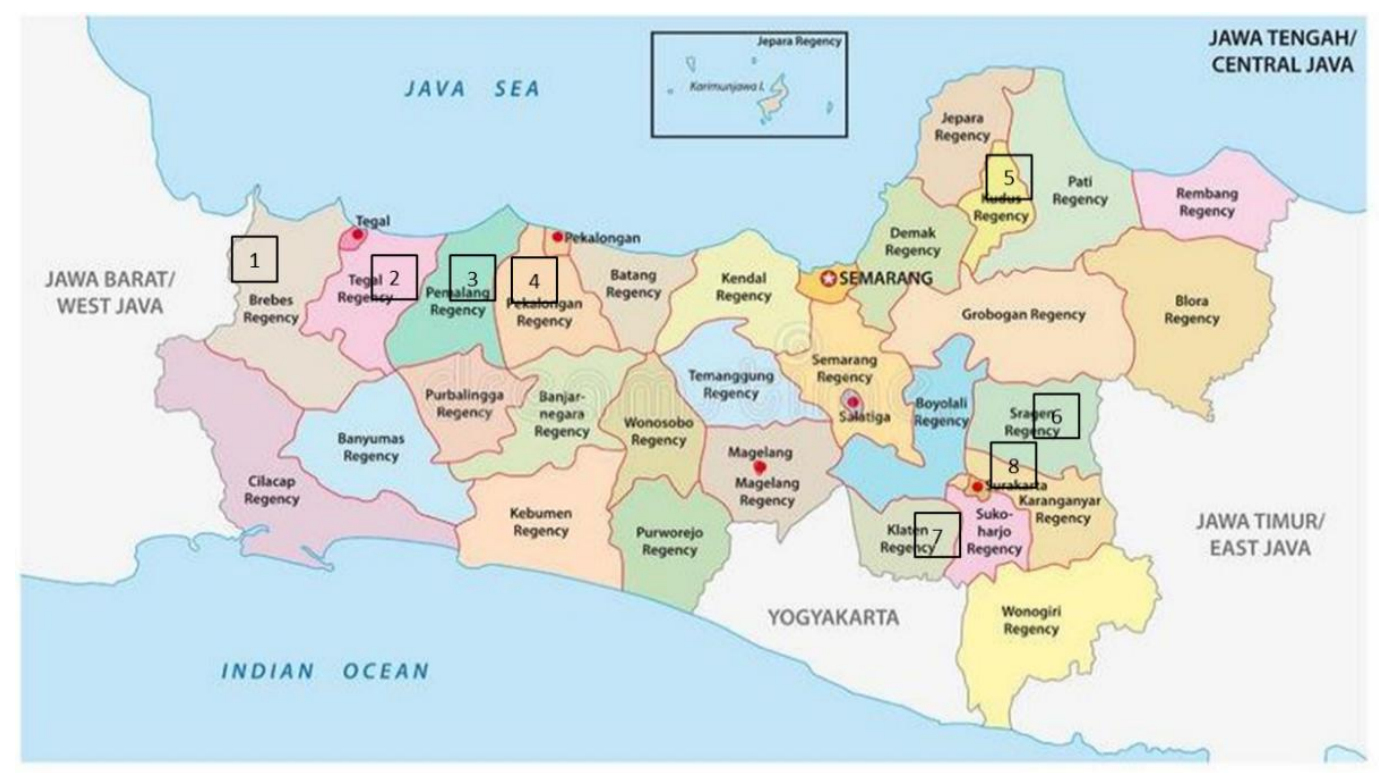

Figure 4. Location Map of the Sugar Factories \& Sugar-Cane Plantations 
To give images of a sugar factory, several examples of sugar factory photos are presented in Figure 5. The three photos show the front face, an aerial view, and a side face of a sugar factory. The three photos were not taken from a single sugar factory.

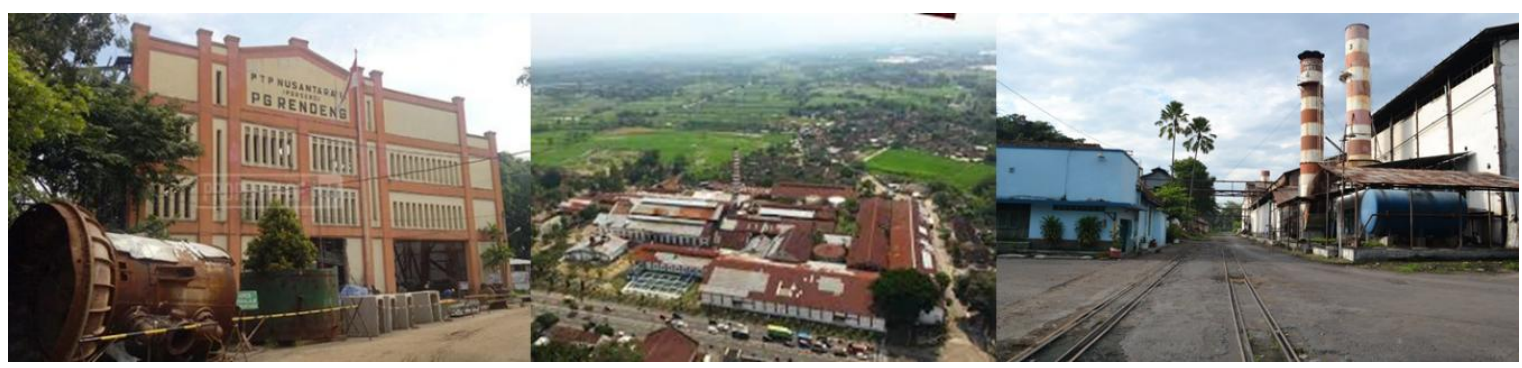

Figure 5. Example of Sugar Factory Photos

\section{AgroTourism, Hotel, Restaurant, and Coffee}

Apart from the yearly plantations and the seasonal plantations (sugar-cane plantations and sugar factories), since several years ago, PTPN-9 develop a new business, i.e. AgroTourism, Hotel, Restaurant, and Coffee. This idea came out after several experiences that the selling price of plantation products are not always stable. They are sensitive to the general trade conjuncture. And also, the new business will maximize the use of the plantations area, the sugar factories area, and help to market the consumption commodities of the PTPN-9. It is also due to the Indonesian Tourism, either domestic and international, which are in general run well. The consumption commodities are tea, coffee, sugar, and nutmeg syrup (PTPN-9, 2017; PTPN-9, 2018).

\section{Agro-Tourism}

The PTPN-9 has 9 Agro-Tourisms Objects, and they are various. Those are located in coffee plantations, tea plantations, and sugar factories. It covers outbound facilities, camping facilities, plantation visit tour facilities, product processing visit facilities. All agro-tourism objects are equipped with a restaurant, coffee, people owned stall (PTPN-9, 2017).

The 8 agro-tourism objects developed in 8 different locations. The list of 8 agro-tourism is presented in Table 3 (PTPN-9, 2018).

Table 3. List of 8 Agro-Tourism Objects

\begin{tabular}{|r|l|l|l|}
\hline No & Name & Activity & Location \\
\hline 1 & Kampung Kopi Banaran & $\begin{array}{l}\text { Coffee, Outdoor, Corporate Gathering, } \\
\text { Meeting, Camping Ground }\end{array}$ & $\begin{array}{l}\text { Bawen, Semarang } \\
\text { Regency }\end{array}$ \\
\hline 2 & Kaligula & $\begin{array}{l}\text { Coffee, tea plantation, tea factory, } \\
\text { outdoor }\end{array}$ & $\begin{array}{l}\text { Paguyangan, Brebes } \\
\text { Regency }\end{array}$ \\
\hline 3 & Jollong & $\begin{array}{l}\text { Coffee Plantation, Outdoor Park } \\
\text { Coffee, tea plantation, tea factory, } \\
\text { outdoor, sport }\end{array}$ & Gembong, Pati Regency \\
\hline 4 & Kampung Teh Semugih & $\begin{array}{l}\text { Moffee, Outdoor, education : coffee } \\
\text { plantation, coffee factory }\end{array}$ & Keling, Jepara Regency \\
\hline 5 & Sentral Park Balong & $\begin{array}{l}\text { coffeee, education : sugar factory, } \\
\text { museum, sugarcane plantation tour } \\
\text { coffee, waterpond activity, outdoor } \\
\text { activity }\end{array}$ & $\begin{array}{l}\text { Jogonalan, Klaten } \\
\text { Regency }\end{array}$ \\
\hline 6 & Gondang Winangoen & $\begin{array}{l}\text { Kawunganten, Cilacap } \\
\text { Regency }\end{array}$ \\
\hline 7 & Waduk Koebangkangkoeng \\
\hline 8 & Sondokoro & $\begin{array}{l}\text { Sugar factory, sugarcane plantation, } \\
\text { outdoor }\end{array}$ & $\begin{array}{l}\text { Tasikmadu, Karanganyar } \\
\text { Regency }\end{array}$ \\
\hline
\end{tabular}


The Location Map of those 8 AgroTourism Objects is presented in the following Figure 6. It can be seen that those eight are located scattered in the whole of Central Java, from east to west and from north to south.

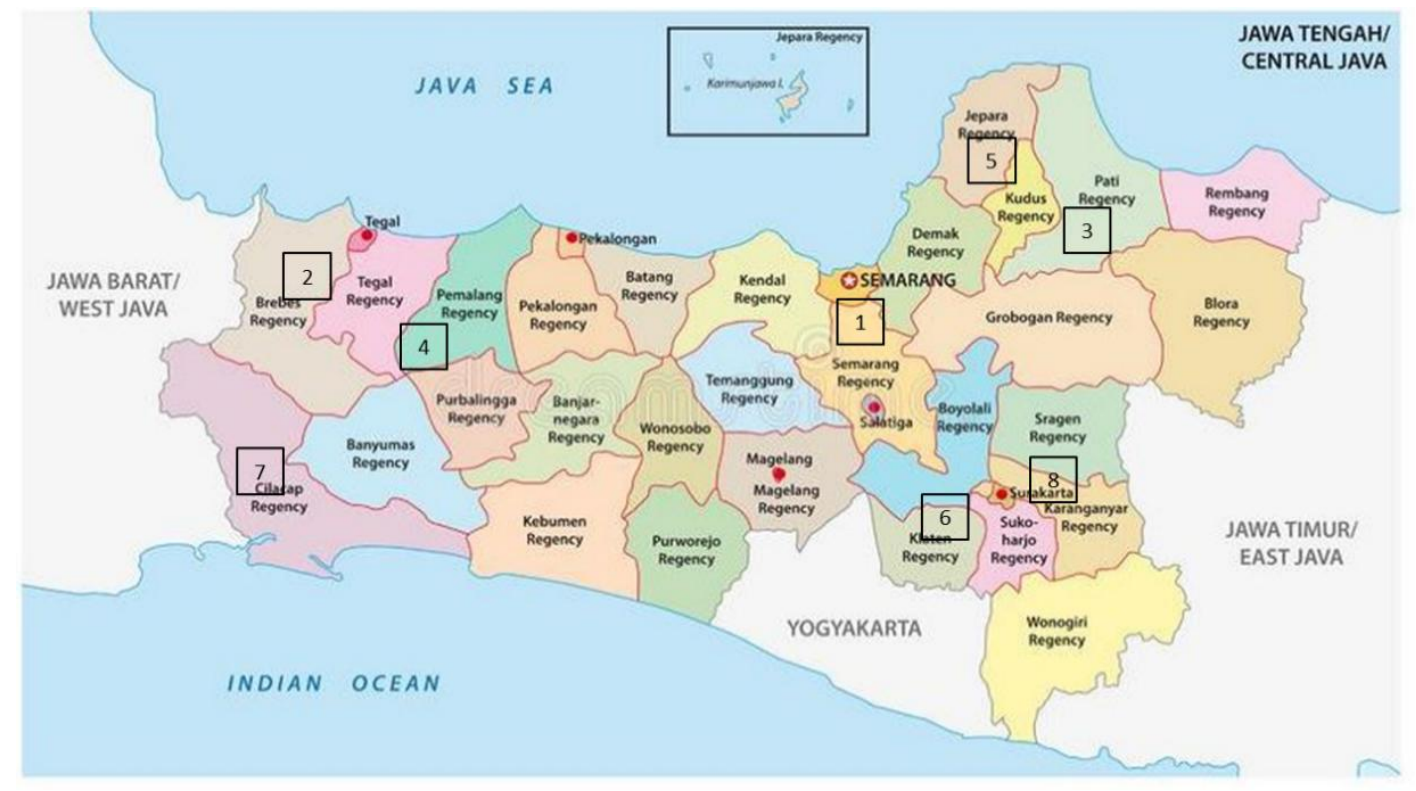

Figure 6. Location Map of AgroTourism Objects

As an illustration, several photos of agri-tourism and hotel are presented in Figure 6 as follows. These photos show the hotel and the agro-tourism in coffee plantations, tea plantations, and sugar factories.

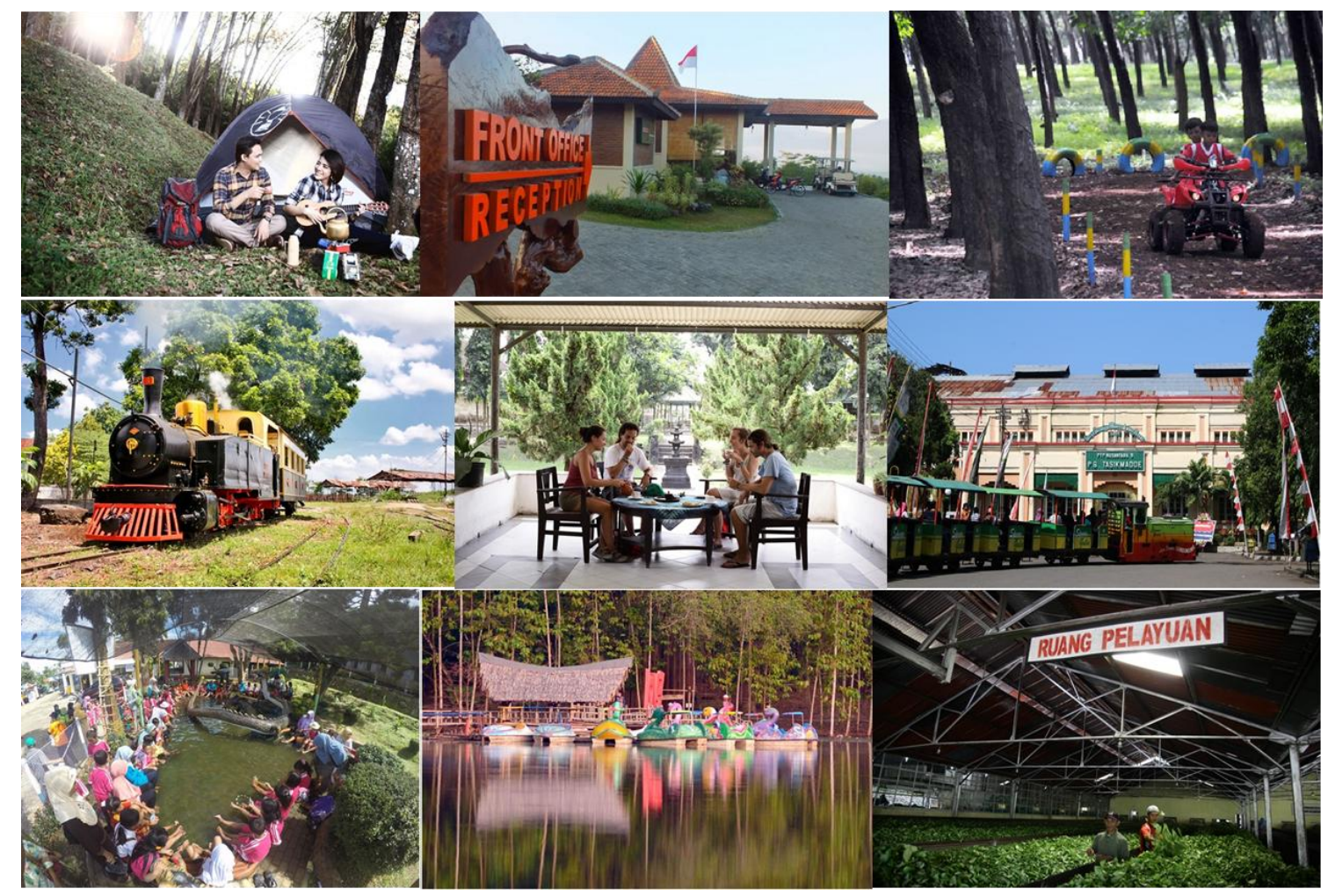

Figure 7. Example of PTPN-9 Agro-Tourism Views 


\section{$\underline{\text { Resort Hotel }}$}

The hotel business is also developed in Banaran Resort, Bawen. This Banaran Resort Hotel was developed to serve MICE (Meeting, Incentives, Conferencing, and Exhibition) activity (PTPN-9, 2017).

\section{$\underline{\text { Restaurant and Coffee }}$}

Restaurants and Coffees were developed, first operated by PTPN-9 itself. Then after several years, PTPN-9 creates franchise mode for anybody who wants to participate. Certain is opened as a restaurant, the others are opened merely as a coffee. This business was already opened in 14 different locations scattered in Central Java. Four of them are organized by Banaran Unit, in Bawen, Gimawang, Majenang, Magelang, and Semarang City (PTPN-9, 2017). The list of 9 of 14 units is presented in Table 4 as follows.

Table 4. List of 9 out of 14 Units Banaran 9 Resto Coffee \& Tea

\begin{tabular}{|c|l|l|l|}
\hline No & Nama & Location & \\
\hline 1 & Kampoeng Kopi Banaran & Bawen & Semarang Regency \\
\hline 2 & Banaran9 Coffee \& Tea Gemawang & Gimawang & Jambu, Semarang Regency \\
\hline 3 & Banaran 9 Resto Warnasari & Majenang & Cilacap Regency \\
\hline 4 & Krumput & & Purwokerto \\
\hline 5 & Colomadu & Jl. Adisucipto & Solo \\
\hline 6 & Banaran 9 Coffee \& Tea Semarang & Jl. Setiabudi & Semarang City \\
\hline 7 & Sindukusuma & Edu Park & Yogyakarta \\
\hline 8 & Rest Area 360 & Batang & Batang \\
\hline 9 & Banaran 9 Resto Coffee \& Tea - Magelang & Jl. Tidar 12 & Magelang \\
\hline
\end{tabular}

As an illustration, several photos of Banaran Restaurant and Banaran Coffee are presented in Figure 7. The photos show restaurants in Bawen, Gimawang, Semarang, and Majenang. Examples of culinary served are also presented.

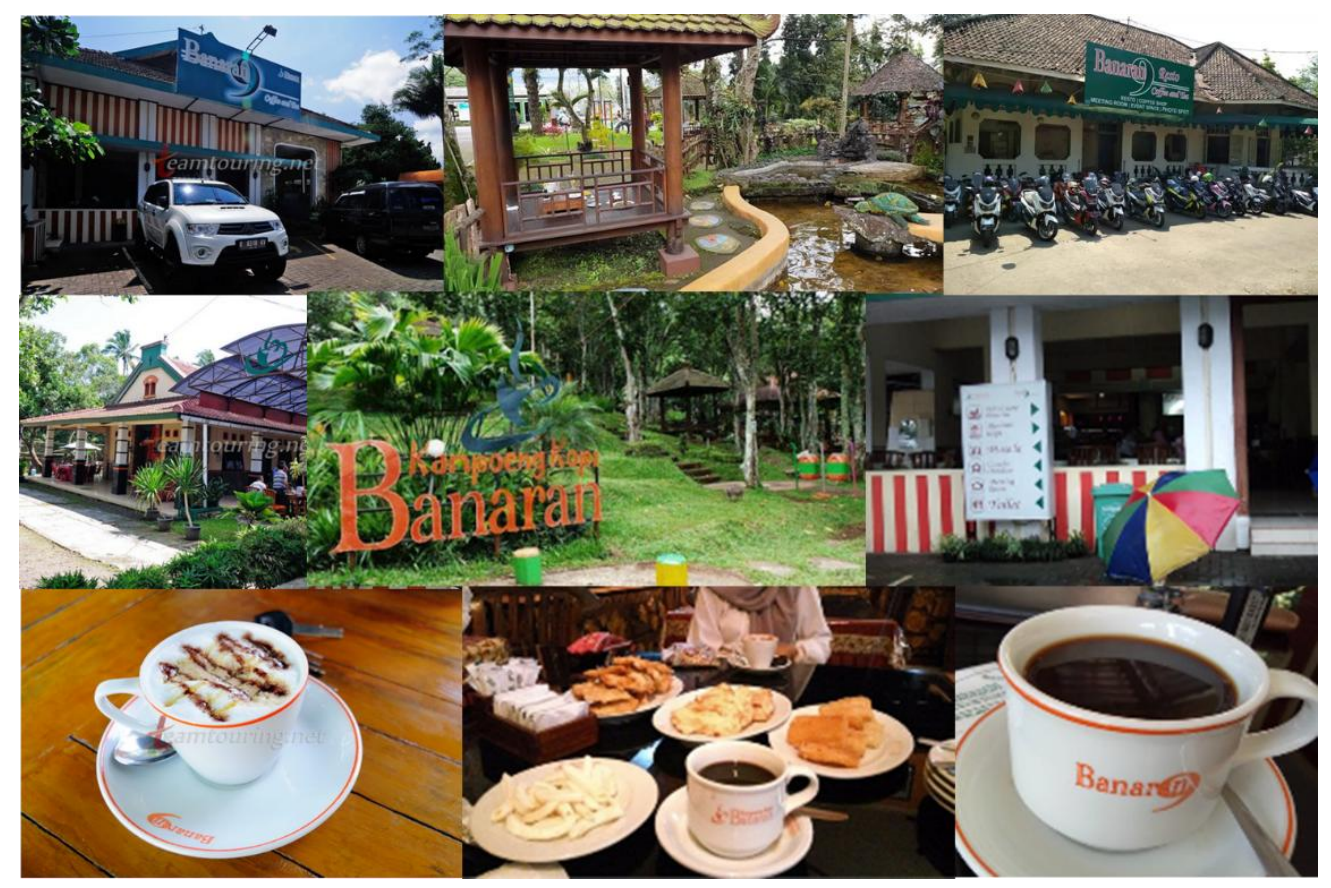

Figure 8. Some Photos of Banaran 9 Resto Coffee \& Tea 


\section{PTPN 9 - Product}

Products and product selling are central to PTPN-9 activities. These need to be well observed. It has been mentioned before that the PTPN-9 has two types of products, i.e. the hard product and the service product. The service product is agrotourism. Agrotourism and related has been discussed before. This sub-chapter is destined to present the hard product (PTPN-9, 2018).

Hard products can be classified as consumption commodities and commercial commodities. Consumption commodity is consumption products directly consumed by the end-user, while the commercial commodities are commercialized for the distributor or industry to be processed for the need of the end-user (PTPN-9, 2018).

\section{Consumption Commodity}

The consumption commodities consist of tea, coffee, sugar, cacao, nutmeg, and lemongrass. The lemongrass is merely fill-in plants, while the cacao and nutmeg plantation is not large. The tea consumption product consists of powder and tea back. The coffee consists of coffee powder and coffee beans. As a consumption product, sugars are produced in sugar crystal. The cacaos are also sold in fermented cacao bean and cacao powder. The nutmegs are marketed as nutmeg syrup and nutmeg oil. Finally, PTPN-9 also produces lemongrass oil, in collaboration with PT. Sinkona Indonesia Lestari (Anonim, 2020; PTPN-9, 2018; Putra, 2017). The list of consumption commodities is presented in Table 5 as follows.

Table 5. Consumption Commodity

\begin{tabular}{|c|l|l|}
\hline No & Product & Producer \\
\hline 1 & Powder Tea Kaligula & Kaligula Tea Factory \\
\hline 2 & Black Tea Powder Semugih & Semugih Tea Factory \\
\hline 3 & Tea Bag Kaligula & Kaligula Tea Factory \\
\hline 4 & Powder Coffee Banaran & Gimawang Coffee Factory \\
\hline 5 & Sugar 9 & All Sugar Factory \\
\hline 6 & Nutmeg Syrup & Nutmeg Factory Kebon Ngobo \\
\hline 7 & Nutmeg Oil & Nutmeg Factory Kebon Ngobo \\
\hline 8 & Lemon Grass Oil & Lemongrass Factory, Unit Siluwok, Batang \\
\hline
\end{tabular}

Several photos of consumption commodities are presented in Figure 8 as an illustration. It can be seen from left to right: coffee bean, sugar crystal, nutmeg syrup, tea powder, and tea back.

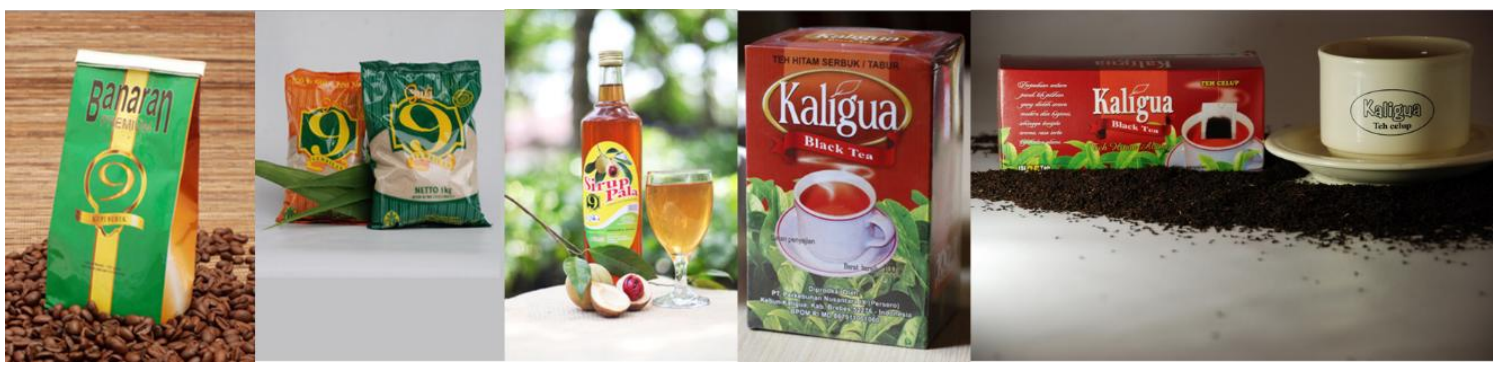

Figure 9. Example of Consumption Commodities

\section{Commercial Commodity}

The commercial commodities sold in gross for the industry and the distributor. This commercial commodity will be used by the industry to produce a more end consumer product 
or another form of commercial commodity, or they are sold to the grand distributor. These cover rubber, tea, coffee, and sugar. Rubber is sold in four forms of a commercial commodity. Tea is sold in two grades. Coffee is sold in four grades. Sugar as consumption commodities are sold in small packs of sugar crystal, while as commercial commodities are sold as sugar crystal in bags and molasses (PTPN-9, 2018; Saraswati \& Sari, 2012).

Table 6. Commercial Commodity Product

\begin{tabular}{|c|l|l|}
\hline No & Product & Producer \\
\hline 1 & Rubber Ribbed Smoke Sheet & Plantation Rubber Workshop \\
\hline 2 & Rubber Thin Pale Crepe & Plantation Rubber Workshop \\
\hline 3 & Rubber Brown Crepe & Plantation Rubber Workshop \\
\hline 4 & Rubber Dark Crepe & Plantation Rubber Workshop \\
\hline 5 & Tea Grade 1 & Plantation Tea Factory \\
\hline 6 & Tea Grade 2 & Plantation Tea Factory \\
\hline 7 & Coffee AWP & Plantation Coffee Factory \\
\hline 8 & Cofee ADP & Plantation Coffee Factory \\
\hline 9 & Coffee RWP & Plantation Coffee Factory \\
\hline 10 & Coffee RDP & Plantation Coffee Factory \\
\hline 11 & Sugar in Bag & Sugar Factory \\
\hline 12 & Molas ses & Sugar Factory \\
\hline 13 & Cacao Fermented Bean & Plantation Cacao Workshop \\
\hline & & \\
\hline
\end{tabular}

\section{Waste Product}

It can be noted that the sugar factory and plantation produce certain waste which can be used and commercialized as fertilizer and livestock food. These are normally sold locally for the surrounding population. The sugar factory, for example, produces sugarcane mud and sugarcane dregs (Agustono et al, 2017; Muhsin,2011; PKG PR, 2012; Yulianti et al, 2005).

\section{PTPN 9 - Product Market}

Again, another important aspect, need to be observed, is the market. The agrotourism, restaurant, and coffee up to nowadays are still consumed by the main domestic market, and also few international tourists. The consumption commodity market is still mainly the domestic market, with certain tea and coffee are already exported. The commercial commodities are for the domestic and international market (PTPN-9, 2017). 
Tabel 7. Product Market

\begin{tabular}{|l|l|l|l|}
\hline \multirow{2}{*}{ Clas S } & Product & Momestic & International \\
\cline { 3 - 4 } & tea & All Region & Asia, Europe \\
\cline { 2 - 4 } $\begin{array}{l}\text { Consumption } \\
\text { Commodity }\end{array}$ & coffee & All Region & Europe, Asia \\
\cline { 2 - 4 } & sugar crystal & All Region & - \\
\cline { 2 - 4 } & nutmeg syroop & All Region & Europe \\
\hline \multirow{4}{*}{$\begin{array}{l}\text { Commercial } \\
\text { Commodity }\end{array}$} & lemongrass oil & All Region & - \\
\cline { 2 - 4 } & tea & All Region & Europe, South East Asia \\
\cline { 2 - 4 } & sugar in bag & All Region & Europe \\
\hline & molas ses & Java & Europe \\
\hline \multirow{2}{*}{$\begin{array}{l}\text { Service } \\
\text { Product }\end{array}$} & Hotel & Java & - \\
\hline & AgroTourism & Local & Several International Tourists \\
\hline & Resto \& Coffee & Java & Several International Tourists \\
\hline
\end{tabular}

\section{CONCLUSION}

The preliminary research has been finished. Observing the PTPN 9 from the Asset Management view is very huge and complex. Several main conclusions can be presented here.

- The PTPN-9 was started in 1957 under a different simpler form of state-owned-enterprise.

- The PTPN-9 is a state-owned-enterprise, under plantation holding company PTPN-3, which is also a state-owned-enterprise.

- The PTPN-9 main functions are to manage the business of state yearly plantations and state seasonal plantations (sugar-cane plantation and sugar factory) in Central Java.

- The production assets consist of 15 yearly plantations, 8 seasonal plantations (sugar-cane plantations and sugar factories), and also 1 resort hotel, 8 points of agro-tourism, 14 restaurants, and coffees.

- PTPN-9 produces service products and hard products. Hard products can be classified as consumption commodities and commercial commodities. Consumption commodities are mainly tea, coffee, cacao, sugar, nutmeg syrup, and lemongrass oil. Commercial commodities are mainly rubber, coffee, tea, and sugar crystal. While the service products are a hotel, agro-tourism, restaurant, and coffee.

- The market covers domestic and international markets. The domestic market mainly for consumer commodities, agritourism, restaurant, and coffee. The international is mainly for commercial commodities.

- PTPN-9, a state-owned enterprise, is a huge and complex institution to be used as a Case Study for developing Knowledge and Science of Asset Management in general, and IFAM more specifically.

This preliminary research has induced several further curiosity, for example observing the general asset management strategy for the production assets, product quality and marketing management, and market assets. A lot of serial papers, on asset management, can be written on PTPN-9 cases, these will be very precious for JIFAM. 
NOTE. This paper is a result of preliminary reflection collaboration between a Former PTPN IX Production Director - Semarang - Indonesia, and Engineers from Dept. of Civil Engineering - Institut Teknologi Sepuluh Nopember (ITS) - Surabaya - Indonesia. This preliminary paper would be further continued toward more detailed discussions. This is a part of Working Papers to develop the Knowledges and Science of Infrastructure \& Facility Asset Management, in Indonesia.

\section{REFERENCES}

Agustono, B., Lamid, M., Ma'aruf, A. \& Purnama, M.T.E. (2017). "Identifikasi Limbah Pertanian dan Perkebunan Sebagai Bahan Pakan Inkonvensional di Banyuwangi”. Jurnal Medik Veteriner, 1(1), Oktober 2017.

Anonim (2020). "Serai Wangi untuk Minyak Atsirin PTPN IX". https://ptpnix.co.id, 12 Agustus 2020,06:00.

Al Bari, M.S., Ekaputri, J.J., Faimun, F., Ariatedja, J.B. \& Gan, B.S. (2019). "Simulation of Concrete Slabe Behavior to Explosion". Journal of Infrastructure \& Facility Asset Management, 1(2), September 2019.

Chilolonga, F.D., Suprayitno, H. \& Dewanti (2020). "Preliminary Research on Air Passenger Volume Variation in Kilimanjaro International Airport Tanzania". Journal of Infrastructure \& Facility Asset Management, 2(2), September 2020.

Eryani, I.G.A.P., Rahadiani, D. \& Yujana, C.A. (2020). "Manajemen Model of Mambal Irrigation Area in the Efforts to Develop Environment-Based Agro-Tourism". Journal of Infrastructure \& Facility Asset Management, 2(2), September 2020.

Firlandy, M.R., Suprayitno, H., Santosa, E.B. \& Adi, T.J.W. (2020). "Influence Factors for Community-Based Road Quality in Slum Settlement Area". Journal of Infrastructure \& Facility Asset Management, 2(2), September 2020.

Fitriningrum, A. (2006). "Indonesian Experience in Managing the State Companies". OECD Asian Roundtable on Corporate Governance Network on Corporate Governance of StateOwned Enterprise, Singapore, 15 May 2006.

ISO 55000. International Standard Organization 55000:2014 - Asset Management - Overview, principles, and terminology.

Key, L.Y. \& Susilawati (2020). "Development of Cell Transmission Model for Traffic Signal Coordination". Journal of Infrastructure \& Facility Asset Management, 2(1), March 2020.

Muhsin, A. (2011). "Pemanfaatan Limbah Hasil Pengolahan Pabrik Tebu Blotong Menjadi Pupuk Organik". Industrial Engineering Conference, 5 November 2011.

Muhtadi, A., Wasono, S.B., Suprayitno, H. \& Ahyudanari, E. (2019). "Potential Number of Passenger and Performance Evaluation of Surabaya School Bus". Journal of Infrastructure \& Facility Asset Management, 1(2), September 2019.

PKG PR (2012). "Sinergi PKG - PTPN IX: Blotong sebagai Bahan Baku Petroorganik". htpps://petrokimia-gresik.com/news, 6 Agustus 2012, 07:42 WIB.

PP 27/14. Peraturan Pemerintah Republik Indonesia Nomor 27 Tahun 2014 tentang Pengelolaan Barang Milik Negara/Daerah.

PTPN-9 (2017). Laporan Tahunan 2017. PT Perkebunan Nusantara IX. Semarang \& Surakarta. PTPN-9 (2018). Katalog Produk. Brosur. PT Perkebunan Nusantara IX, Semarang \& Surakarta. Putra, A.P. (2017). "Foto Perkebunan Jateng Hasilkan Pala Eksport". SoloPos.com, Jum 'at, 22 September 2017, 03:50 WIB.

Ratnasari, V. \& Suprayitno, H. (2019). Learning JIFAM by Using Its Medical Center as a Case: \#1 - Identifying the Function, Medical Services, Infrastructure \& Facility. Journal of Infrastructure \& Facility Asset Management 1(2), September 2019.

Saraswati, M. \& Sari, S.M. (2012). "PTPN IX segera operasikan dua pabrik karet". Bisnis.com, Ekonomi, 12 Januari 2012, 18:50 WIB. 
Slamet, F.F. \& Fajarwati, N. (2020). "Evaluasi Kinerja Aset Fasilitas Wisata Domba di Kabpaten Garut". Jurnal Manajemen Aset Infrastruktur \& Fasilitas, 4(3), Juli 2020, 183 194.

Soejono, F. (2010). "Ownership Type and Company Performance: Empirical Studies in the Indonesian Stock Exchange". Journal of Indonesian Economy and Business, 25(3), 2010, 338-352.

Soejono, F. \& Heriyanto (2018). "Privatization and Firm Performance: a Study of Indonesian State-Owned-Enterprise". Jurnal Dinamika Manajemen, 9(2), 2018, 149-158.

Soemitro, R.A.A. \& Suprayitno, H. (2018). Pemikiran Awal tentang Prinsip Dasar Manajemen Aset Fasilitas. Jurnal Manajemen Aset Infrastruktur \& Fasilitas, 2(Sup1), Juni 2020.

Soemitro, R.A.A. \& Suprayitno, H. (2020). "Preliminary Reflection on Basic Problematics of National Public Infrastructure Financing in Indonesia". Journal of Infrastructure \& Facility Asset Management, 2(1), March 2020,

Suprayitno, H (2015). “Traffic Flow Quality as Part of Network Quality for Sparse Rod Network". Proceedia Engineering 125, 564-570, Elsevier.

Suprayitno, H. \& Soemitro, R.A.A. (2018). Preliminary Reflexion on Basic Principle of Infrastructure Asset Management. Jurnal Manajemen Aset Infrastruktur \& Fasilitas 2(1), Maret 2018.

Suprayitno, H., Soemitro, R.A.A., Maulana, M.A. \& Hesna, Y. (2020). "Preliminary Reflection on Performance Indicator and Performance Factor for Infrastructure Asset Management". Journal of Infrastructure \& Facility Asset Management, 2(1) March 2020.

Teguh, N.A., Lasminto, U., Darmanegara, A.A.N.S. \& Anshori, M.B. (2020). "Evaluation of Pump Capacity in Pancasila Pumping Station, Madiun City, East Java". Journal of Infrastructure \& Facility Asset Management, 2(2), September 2020.

UU 1/04. Undang-Undang Republik Indonesia Nomor 1 Tahun 2004 tentang Perbendaharaan Negara.

Yulianti, Winarno \& Mudyantini (2005). "Pemanfaatan Limbah Cair Pabrik Karet PTPN IX Kebon Batu Jamus Karanganyar Hasil Fiteromediasi dengan Azzola Micophylla Kaulf untuk Pertumbuhan Tanaman Padi (Oryza Sativa Linn.)". BioSMART, 7(2), Oktober 20015, 125-130. 